\title{
Analyzing Characteristics and Trends of Economic Growth in the Sectors of National Economy of Uzbekistan
}

\author{
Ziyodilloev Khushnud* \\ School of Economics \\ Beijing Technology and Business University \\ Beijing, China \\ xushnud.ziyodilloyev@mail.ru \\ Shomurodov Tokhir \\ School of Economics \\ Beijing Technology and Business University \\ Beijing, China \\ tohirbek0206@gmail.com
}

\author{
Qingjie Zhou \\ School of Economics \\ Beijing Technology and Business University \\ Beijing, China \\ zhouqj@btbu.edu.cn \\ Hong'en Yang \\ School of Economics \\ Beijing Technology and Business University \\ Beijing, China \\ y_paper@126.com
}

\begin{abstract}
One of the most effective ways to achieve economic growth is structural transformation and diversification of main sectors in national economy, which focusing on the economic potential of the sectors, the development of new industries. This paper examines of economic growth in sectors of national economy, impact factors on structures of economy and analyzed data by using econometric models, some conclusion and also proposals are given according to results for the government. The research paper try to answer for "Does the process of globalization and resultant changes in sectors of economy offer new opportunities for the developing country led with growth or will it further marginalize excluded? The paper investigated on economy sectors of Uzbekistan. The factors that cause exclusion are examined both in terms of globalization forces and domestic shortcomings in policies and governance.
\end{abstract}

Keywords: economic growth, structural changes, 'linkage' concept, structural growth, Uzbekistan

\section{INTRODUCTION}

One of the most effective ways to achieve economic growth is structural transformation and diversification of the main sectors of economy. It can be achieved greater efficiency in the use of directing investments in the national economy, mainly focusing on the economic potential of sectors, the development of new industries, thereby ensuring the sustainability of economic growth. Recently, Uzbekistan is implementing ambitious market-oriented economic reforms. The authorities unified the exchange rate and liberalized the foreign exchange market starting in September, 2017, began price and trade liberalization, made significant cuts to tax rates for both firms and individuals from January, 2019. The country's opening to the world included elimination of entry visas to promote tourism and business and also a renewed commitment to join the World Trade Organization (WTO).
Once, the industrial and agriculture development was considered to be a best tool to enhance economic growth of a country, every country gave more focus and importance to these sectors in its plans and policies, but now the trend has changed, because the advancement and development of these two major sector of an economy sustain on the development of other factors, the role of service sector, advancement in technology, and the contribution of foreign sector in economic growth by different ways increases, and the major area of interest for foreign sector or investment was service sector and still it is, countries with the existence of General Agreement on Trade in Services (GATS), started to privatize their set up, and also after realizing the importance of communications and services, the telecommunication sector is on their main priorities nowin most countries. Data indicated that with the advancement of telecommunication services: a new market mechanism, low cost structure and expanded value chain of firms is possible (Kambil and Short, 1994), especially in developing countries, the average price of agricultural commodities is high in the area where there is telephone facilities available than the area where there is no facilities to communicate (Bayes et al (1999).

All the Central Asian countries (include Uzbekistan) suffer from rampant corruption; weak rule of law; poor law enforcement; unpredictable, complicated trade and customs policies; an underdeveloped framework for the implementation of public-private partnerships; and an unpredictable and excessive tax and burden. The authorities have undertaken ambitious reforms that have delivered improvements to Uzbekistan's business and investment climate and also are likely to boost economic growth over the medium term. Reforms include changes to the currency and tax systems, the lifting of state monopolies in some sectors (for example, fruit and vegetable exports) and the opening of the banking sector to foreign investors. The government has also opened the previously-closed borders with Uzbekistan's neighbors and has

*Corresponding author 
initiated regional transport links to foster new trade and investment opportunities in Central Asia. It is important to mention that the government's medium-term economic reform priorities through 2021, include improving business environment for the private sectors; introducing public-private partnerships (PPPs); strengthening the corporate governance of state-owned enterprises (SOEs) and subsequently carrying out selected privatizations; reforming agriculture mainly reducing land under cotton cultivation, introducing direct contracts for cotton farms with textile companies.

Relationship between economic growth and structural sectors and share contribution of the sectors of national economy are particularly significant and complicated, also need to mention give the lack of diversified, undefined methods and procedures, Nowadays, government focus on more attention is sectorial growth in the economy. This research paper focuses on examine economic growth in sectors of national economy, impact factors on structures of economy and analyzed data by using econometric models, some conclusion and also proposals are given according to results for the government.

\section{THEORETICAL BACKGROUND}

According to Austrian economist M. Landesmann (1978), the concept of structural change and structural development can be implemented in two stages: 1) a change in structure which production, number of jobs, export, import, etc.and 2) changes in the relationship between productive and working relations, or the dynamics of import-export direct investment, etc. Structural changes are the quality and evolutionary development of economic systems. As a rule, structural changes in the economy are observed in technological and administrative changes. Technologies, literacy levels and institutional units that are important factors in the economy have a significant impact on the structure of economic growth. Given the history of research into the structural aspects of economic growth and transformation of the economy, it was the focus of attention of all the greatest scientists in the world.

Hazell and Roell (1983), in the early stages of development rising incomes of rural-farming households is essential to providing market for domestically produced goods and services via strengthened purchasing power. The most direct contribution of agriculture to economic growth, Irz et al. (2001) is increase in incomes of farmers and therefore their purchasing power. This sectorial growth increases the incomes and therefore purchasing power of farmers resulting in a vibrant domestic market for other sectors, hence growth in the economy. Inclusive growth processes are based on the principles of macroeconomic stability, human capital, structural transformations, inclusive growth on the freedom of foreign investments and foreign trade R. Anand (2002), S. Mishra (2004). In the above studies, employment, labor productivity, structural changes are considered as the leading indicators. Results of several studies, including Gallup et al. (1997), Irz et al. (2001) and Thirtle et al. (2001), show that an increase in agriculture growth results in an increase in the income level of the poorest of the population.

Also, results from cross-country regressions among developing countries show that $\$ 1$ increase in GDP results in significantly more poverty reduction when the growth is in agriculture rather than other sectors (Lipton, 2012).

Hirschman (1958) first defined the concept of 'linkage' in his work "The Strategy of Economic Development". He emphasized the significance of 'unbalanced' growth among supporting sectors of the economy as opposed to a balanced development of all interrelated economic activities (Lean, 2001). Park (1989) has confirmed that the construction industry generates one of the highest multiplier effects through its extensive backward and forward linkages with other sectors of the economy. It is stated that the importance of the construction industry stems from its strong linkages with other sectors of the economy (World Bank, 1984). However, interdependence between the construction sector and other economic sectors is not static (Bon, 1988; Bon, 1992). Strout (1958) provided a comparative inter-sectoral analysis of employment effects with an emphasis on the construction. Ball (1965) and Ball (1981) addressed the employment effects of the construction sector as a whole.

According to findings data, it is necessary to analyses extensive backward and forward linkages with one sector to another sector of the economy, in case of Uzbekistan, the data confirmed that construction industry generates one of the highest multiplier effects through forward linkages with other sectors. A study of Yilmaz, et al. (2001) indicated that the accumulation of telecommunication infrastructure improves the overall productive capacity at the regional level by examining the impact of telecommunications infrastructure on economic output both at the aggregate and sectorial levels in the United States. Wallsten (2002) used data on telecommunication industry worldwide to analyze whether the sequence of reforms matters. Fink et al. (2002) used data on 86 developing countries worldwide to analyze the impact of telecommunication policy reforms on industry performance. The result has been confirmed by more recent analysis of economic growth in OECD by Datta and Agarwal (2004) which indicates that telecommunications infrastructure plays a positive and significant role in economic growth using a similar but not identical the same data as Roller and Waverman (2002), includes 22 OECD countries.

Categorically, human capital played a pivotal role in the economic growth of many countries (Tahir and Azid, 2015). Investment in human capital are expenditures on health, on all type of education, including job-training, increase the quality of labor force and its ability to perform productive tasks ( Barro 2003; Sachs and Warner 1997). Production of knowledge is as the clue to technological progress (Radelet, Sachs, and WhangLee 2001). Human capital theory (HCT) strongly supports the view of the developing human resources. The main proposition of the theory is that the people are being treated as a form capital for the development. From that, the human development in terms of education and schooling is considered as a direct and deliberate investment in the labor force. Covering the period 1965-1990, Radelet, Sachs, (2001) investigated the determinants of economic growth in 18 Asian countries. Results revealed that initial education, coastline land area, government savings, trade openness, quality of institutions, life expectancy and growth of working age population were positively. 


\section{MACROECONOMIC INDICATORS AND MAIN SECTORS OF THE ECONOMY}

Ensuring economic growth in the country along with improving the welfare of the population contributes to the appreciation of the national currency, reducing external debt and reducing inflation. As a result of the economic reforms carried out in Uzbekistan, past two recent years, the economy has shown stable growth, the country's external debt has decreased, and the per capita GDP has been gradually increasing. This is the result of a balanced development, modernization and diversification of economic sectors. Analysis of changes in the sectorial structure of the economy of Uzbekistan in 1991-2017 is shows that the industry, ensuring the acceleration of the development of science and technology in industrial production, are developing rapidly and other progressive changes are occurring. The main goal of economic development of Uzbekistan is not only the pursuit of growth in economic sectors, but also the creation of a set of measures for the development of priority sectors, its modern structure, competitiveness and efficiency of domestic industry in the domestic and foreign markets through the use of rich natural resources. (Sh. Abdullaeva and A. Amonov, 2010)

TABLE I. MACROECONOMIC INDICATORS OF UZBEKISTAN

\begin{tabular}{|c|c|c|c|c|c|c|}
\hline Main indicators & 2013 & 2014 & 2015 & 2016 & 2017 & 2018 \\
\hline GDP growth, $(\%)$ & 8,3 & 8,2 & 8,1 & 8,1 & 7,6 & 5,3 \\
\hline $\begin{array}{l}\text { GDP per capita, current } \\
\text { (USD) }\end{array}$ & 1545 & 1719 & 1878 & 2038 & 2146 & 2053 \\
\hline $\begin{array}{c}\text { Average annual } \\
\text { population, (million } \\
\text { people) }\end{array}$ & 29,3 & 29,8 & 30,2 & 30,8 & 31,1 & 34.5 \\
\hline $\begin{array}{l}\text { Gross investment to main } \\
\text { capital in GDP (\%) }\end{array}$ & 23,5 & 22,8 & 23,2 & 23,3 & 26,1 & 29,9 \\
\hline $\begin{array}{c}\text { Inflation (consumer price } \\
\text { index, by the end of the } \\
\text { year), }(\%)\end{array}$ & 7,3 & 7,0 & 6,8 & 6,1 & 6,3 & 7,0 \\
\hline $\begin{array}{c}\text { Current account balance in } \\
\text { GDP, }(\%)\end{array}$ & 5,8 & 1,2 & 1,9 & 1,6 & 0,3 & 0,9 \\
\hline $\begin{array}{l}\text { Fiscal balance in GDP, } \\
(\%)\end{array}$ & 8,8 & 5,1 & 3,8 & 2,6 & 2,0 & 2,2 \\
\hline $\begin{array}{c}\text { Foreign direct investment } \\
\text { in GDP, }(\%)\end{array}$ & 3,6 & 1,7 & 1,7 & 1,0 & 1,0 & 1,3 \\
\hline Remittances in GDP, $(\%)$ & 5,9 & 6,8 & 6,4 & 5,1 & 6,9 & 7,1 \\
\hline External debt in GDP, (\%) & 18,6 & 17,3 & 16,5 & 17,0 & 17,1 & 17,9 \\
\hline
\end{tabular}

According to findings data, from the first years of independence until 2002-2003, the agricultural sector was the leading sector in the overall production structure, and since 2007, the share of agriculture in GDP has declined significantly. When analyzing the data in Table 2 , the proportion of agriculture in GDP in 2010 was $17.9 \%$, which is $17.3 \%$ in 2017. Despite the decline in the share of agriculture in GDP, the share of livelihoods in rural areas has not decreased. Since 2008, the industry share has been growing steadily and becoming the leading industry. The share of industry in total production in 2010 was $23.8 \%$ of the total, whereas by 2017 this indicator was $24.1 \%$ and a quarter of gross domestic product was created in this sector. The growth of industrial production 20 times over the last decade emphasizes the importance of the role of industry in the economy. Indeed, the role of technology and innovation as major factors contributing to facilitating entry into global markets, maintaining competitiveness and boosting export performance were the subject of some empirical studies (DiPietro and Anoruo, 2006; Bhattacharya and Bloch, 2004).

In Uzbekistan, industry is the main sector of the national economy with more than 1.5 million workers and employees. This is a third of the population involved. $40 \%$ of fixed assets belong to the industrial sector, and a third of investments in fixed capital is divided into industry. The industry has more than 100 sectors, of which 6 are basic. One of the main sectors of the economy is construction. Significant investment in the economy recent years has been associated with the construction sector and this figure is increasing from year to year. Data showed that the share of the construction sector in GDP is growing steadily from year to year. In the period from 2010 to 2017, we can see that the sector's share in GDP represents 0.9 percent per year. Correlation and regression analysis based on the following gives an idea of the extent to which GDP affects the main sectors of economy. Diversification of the industrial structure in recent years, the structure of exports has changed in the republic and the increase in export of almost all groups of goods and services is observed, the export of finished products predominated over the export of raw materials.

TABLE II. SHARES OF SECTORS IN THE ECONOMY OF UZBEKISTAN, GDP $(\%)$

\begin{tabular}{|c|c|c|c|c|c|c|c|c|}
\hline $\begin{array}{c}\text { Sectors } \\
\text { indicators }\end{array}$ & 2010 & 2011 & 2012 & 2013 & 2014 & 2015 & 2016 & 2017 \\
\hline GDP & 100 & 100 & 100 & 100 & 100 & 100 & 100 & 100 \\
\hline Industry & 23,8 & 24 & 24 & 24,1 & 24 & 24,2 & 25,6 & 24,1 \\
\hline Agriculture & 17,9 & 17,8 & 18 & 17,4 & 17,4 & 16,7 & 17,6 & 17,3 \\
\hline $\begin{array}{c}\text { Constructi } \\
\text { on }\end{array}$ & 6,4 & 6,1 & 6,3 & 6,5 & 6,8 & 7,3 & 7,2 & 6,1 \\
\hline $\begin{array}{l}\text { Transport } \\
\text { and } \\
\text { services }\end{array}$ & 11,5 & 11,7 & 11,9 & 11,8 & 11,4 & 11 & 12,4 & 9,8 \\
\hline Trade & 9,2 & 9,3 & 8,8 & 8,8 & 8,7 & 8,3 & 10,5 & 10,3 \\
\hline Others & 30,8 & 31,1 & 32,1 & 31,5 & 31,8 & 32,4 & 26,7 & 32,4 \\
\hline
\end{tabular}

Source: State Statistics Committee of the Republic of Uzbekistan 
Therefore, for the growth of the national economy and for household's life, remittances are significant factor. Data indicated that total remittance inflows to Uzbekistan remained broadly stable in 2018 , almost $\$ 5.7$ billion but grew as a share of GDP owing to exchange rate devaluation. According to data that remittances came mostly from Russia (77 percent of the total), Kazakhstan (6 percent), United States (4 percent), Turkey (4 percent), South Korea (2 percent) and Israel (1 percent). Also, labor migrants finding jobs abroad totaled 2.6 million in 2018 (according to World Bank database).

TABLE III. TOTAL REMITTANCE INFLOWS TO THE ECONOMY OF UZBEKISTAN

\begin{tabular}{|c|c|c|c|c|c|c|}
\hline Indicator & $\mathbf{2 0 1 3}$ & $\mathbf{2 0 1 4}$ & $\mathbf{2 0 1 5}$ & $\mathbf{2 0 1 6}$ & $\mathbf{2 0 1 7}$ & $\mathbf{2 0 1 8}$ \\
\hline $\begin{array}{c}\text { Remittances, in } \\
\text { GDP (\%) }\end{array}$ & 5,9 & 6,8 & 6,4 & 5,1 & 6,9 & 7,1 \\
\hline $\begin{array}{c}\text { TOTALLY, } \\
\text { Billion \$ }\end{array}$ & - & - & 4,0 & 4,3 & 5,7 & 5,9 \\
\hline
\end{tabular}

Robust economic growth has not translated into substantial employment generation. The total number of jobs offered on the domestic labor market in 2018 was estimated at 1,061,100. However, this is well below the number of jobs needed (more than 1.3 million). Data showed that Uzbekistan's labor force was 18.8 million in 2018, consisting of an economicallyactive population of 14.6 million and an economically-inactive population of 4.2 million. A total of 13.2 million people were employed, of which 5.3 million held jobs in the formal sector and 7.9 million (or 59.3 percent of total employment) were employed informally. Of the 7.9 million jobs in the informal sector, the number of workers employed in seasonal and temporary informal jobs was 1.6 million; labor migrants finding jobs abroad totaled 2.6 million in 2018. Uzbekistan's sectorial employment structure has remained relatively unchanged in the last decade. We can say that Uzbekistan relied heavily on a state-driven, import-substitution growth model from the early 1990 s to 2018 , with mixed outcomes for job creation and living standards.

\section{DATA COLLECTION AND METHODOLOGY}

This research has been carried out in order to investigate the impact of various macroeconomic variables on the GDP growth. Research paper data collected from two main different sources which these are internal and external to the subject of research. We used to collect information primary and secondary data for conducting this paper it is necessary to say that all secondary sources are gathered figures, statistics and facts collected to get information, such our secondary data gathered from various literature, it may include electronic sites, books, different journal, research paper which done by other people before. Mainly, the research is based on secondary data of Statistical committee of Uzbekistan, to compile the report with some variables cover the period from 2000 to 2018 .

Impact of various macroeconomic variables on GDP has been studied with the help OLS regression and ADF test employed for testing unit root analysis by using Stata software. Our model equation is shown below:

$$
\mathrm{Ln}_{t}=\beta_{0}+\beta_{1^{\ln A G R}} t^{+} \beta_{2^{\ln }} \mathrm{CONSTR}_{t}+\beta_{3} \ln \mathrm{TR}_{t}+\beta_{4} \ln \mathrm{SERV}_{t}+\mu
$$

Here: ${ }^{\beta_{0}}$ constant $\beta_{1}, \beta_{2}, \ldots \beta_{4}$ : coefficients AGR: agricultural production rate (mln. USD) CONSTR: all done construction projects (mln. USD) TR: sum of exports and imports (mln. USD) SERV: total amount of services for a given period (mln. USD), $\mu$ : error term.

\section{ECONOMETRIC RESULTS AND DATA ANALYSIS}

Prior to regression analysis of the model it is vital to find out the order of integration among the variables especially in case of time series data. If the data is co-integrated of order I (2), the F-stat results are not applicable or any prominent regression method (Ouattara, 2004). That's why, before going to regression analysis of variables the data used in this study for GDP growth and its determinants and of Uzbekistan as well as other variables were tested by Augmented DickyFuller (ADF) unit root to find out the order of integration and level of stationary of variables as well as any evidence of spurious relation that had remains one of main concern of the researchers. The results of the ADF test shows that the variables are integrated of order I (0) and I (1) while none of the variables at I (2). Moreover, data also didn't show any sign of spurious relation and outliers.

TABLE IV. UNIT ROOT TEST RESULTS (AUGMENTED DICKEYFULLER)

\begin{tabular}{lcccc}
\hline \multicolumn{1}{c}{ Variables } & Acronyms & ADF Values & $\begin{array}{c}\text { ADF } \\
\text { Critical } \\
\text { Values }\end{array}$ \\
\hline $\begin{array}{l}\text { Economic } \\
\text { Growth }\end{array}$ & GDP & 0.3369 & $-4.890^{*}$ & -3.750 \\
\hline $\begin{array}{l}\text { Agriculture } \\
\text { Construction }\end{array}$ & AGR & 0.6478 & $-2.259^{* *}$ & -3.750 \\
& CONST & 0.7097 & $-4.113^{*}$ & -3.750 \\
\hline Trade & TR & 0.1645 & $-3.523 * *$ & -3.750 \\
\hline Service & SERV & 0.7905 & $-6.892^{*}$ & -3.750 \\
\hline
\end{tabular}

Note: (i) $* * *$ and $* *$ indicates significant at $1 \%$ and $5 \%$ critical level. 
All our variables are normally distributed according to Skewness/Kurtosis tests for Normality distribution, since all probability chi2 values are insignificant at $95 \%$ confidence level.

\section{TABLE V. SKEWNESS/KURTOSIS TESTS FOR NORMALITY}

----- joint -----

\begin{tabular}{cccccc}
\hline Variable & Obs & $\begin{array}{c}\text { Pr } \\
\text { (Skewness) }\end{array}$ & $\begin{array}{c}\text { Pr } \\
\text { (Kurtosis) }\end{array}$ & $\begin{array}{c}\text { adj } \\
\text { chi2(2) }\end{array}$ & Prob>chi2 \\
\hline GDP & 12 & 0.5987 & 0.4588 & 0.90 & 0.6366 \\
\hline AGR & 12 & 0.3652 & 0.4066 & 1.74 & 0.4195 \\
& & & & & \\
\hline CONSTR & 12 & 0.6134 & 0.6376 & 0.49 & 0.7817 \\
& & & & & \\
\hline TR & 12 & 0.1554 & 0.1413 & 4.39 & 0.1115 \\
& & & & & \\
\hline SERV & 12 & 0.8837 & 0.3430 & 1.02 & 0.6013
\end{tabular}

We can see that table $\mathrm{V}$ defines AGR, CONSTR, and SERV as statistically significant and values possessed $0.3451597,0.121249$ and 0.3640658 respectively. Here AGR implies that $1 \%$ increase in Agricultural production will increase .3451597 in real GDP per capita in the economy. Similarly, if capital increases by $1 \%$ it will lead to more than $1 \%$ increase in real GDP per capita. Again, unexpected result trade is negatively and insignificantly related with GDP per capita; here it shows that $1 \%$ increase in trade will reduce $0.138207 \%$ in real GDP per capita during sample period.

\section{TABLE VI. OLS REGRESSION RESULTS}

\begin{tabular}{ccccccc}
\hline GDP & Coeff. & Std. Err. & $\mathbf{t}$ & $\mathbf{P}>\mathbf{t}$ & {$[\mathbf{9 5 \%}$ Conf. Interval] } \\
\hline AGR & 0.3451597 & .024307 & 14.20 & 0.000 & .2856827 & .4046366 \\
& & & & & & \\
\hline $\begin{array}{c}\text { CONS } \\
\text { TR }\end{array}$ & 0.1212491 & .047288 & 2.56 & 0.043 & .0055396 & .2369586 \\
\hline TR & -0.138207 & .052391 & 2.64 & 0.069 & .0100116 & .2664037 \\
& & & & & & \\
\hline SERV & 0.3640658 & .0797389 & 4.57 & 0.004 & .1689517 & .5591798 \\
& & & & & & \\
\hline _cons & 0.242693 & .4748172 & 0.51 & 0.628 & .9191428 & 1.404529
\end{tabular}

In 2017, Uzbekistan changed course, placing the country on track to build a more open and market-oriented economy. Despite a slowdown relative to historical averages, Uzbekistan's economic outlook remains positive, with real
GDP growth projected at 5.3 percent in $2019,5.5$ percent in 2020 , and 6 percent in 2021. Creating productive jobs is the key to economic growth and improvement in living standards. It is significant to mention that in the same time, Uzbekistan carried out foreign trade operations with 175 countries around the world and reached a positive balance with 86 countries. Recently, the government has approved the Sustainable Development Goals (SDGs) to national needs, including plans to help vulnerable groups, with 16 national SDG goals with 127 related targets. The additional spending needs for achieving SDGs are estimated by IMF at around 9 percent of GDP each year until 2030.

\section{RESEARCH CONCLUSION AND RECOMMENDATIONS}

The two key factors contributing to growth in GDP per capita in Uzbekistan are growth in labor productivity and growth in employment. The economies that today have the highest incomes per capita are also those that have shown the most impressive increases in labor productivity growth over the past two decades. This increase in productivity has led to the creation of better or higher-paying, jobs. GDP per capita is, in fact, a measure of the population's productivity, and differences in GDP per capita between high-income and lowincome economies largely reflect differences in their levels of labor productivity. Many of Uzbekistan's sectors and subsectors experienced simultaneous growth in employment and labor productivity. This was the case in construction, chemicals, petrochemicals, wholesale and retail trade and catering services, transport and communications, and other services subsectors. While the electricity industry and two subsectors of the mining sector (the fuel industry and the metallurgical industry) created jobs, they also experienced a decline in labor productivity.

Uzbekistan once played an important role in the old Silk Road, but this region has not appeared on the global stage for several centuries. Since the collapse of the Soviet Union, Central Asian countries, include Uzbekistan have faced tremendous political, economic and social difficulties.

Findings are support that new strategies will guide the government's priorities. According to Drucker (1999) and Porter (1998), human capital not only influences the economic growth, but also increases national competitiveness. Moreover, human capital affects the growth of other kinds of the capital such as physical (Lange and Topel, 2006). In recent times, the issues of human capital development are increasingly emerging as the most important field of scientific research which indicates there is still a gap in the body of knowledge (Vaitkevicius et al., 2015). The government adopted the "Strategy for Innovative Development" in September 2018, which includes quantitative targets for 81 indicators to be achieved through 2030. The Strategy prioritizes human development as a key factor in competitiveness, emphasizes basic and tertiary education. 


\section{ACKNOWLEDGMENT}

We would like to thank Dr. Zhou Qingjie and Dr. Yang Hong'en for supporting and thoughtful suggestions, helped us through several part of the paper. We write to extend our warmest gratitude to Beijing Technology and Business University for giving this opportunity, International Business School, YUFE to attend International Conference.

\section{REFERENCES}

[1]. Akhtar, H., and Waqar, H. (2004), "Liberlizing Telecom Sector in Pakistan", Issues and Prospects, B.Z University Multan, Pakistan.

[2]. Ball, C.M. (1965), "Employment effects of construction expenditures", Monthly labor Review, 88, 154-158.

[3]. Beil, O.R., Ford, G., and Jackson, D. J. (2002), "On the Relationship between Telecommunication Investment and Economic Growth in the United States", Telecommunication Department Research Center, Florida.

[4]. Bon, R., Birgonul, T. and Ozdogan, I. (1999), "An input- output analysis of the Turkish construction sector", 1973-1990: a note. Construction Management and Economics, 17, 543-51;

[5]. Gollin, D., Parente, S.\& Rogerson, R. (2002). The Role of Agriculture in Development; The American Economic Review, 92 (2), 160-164.

[6]. Hazell, P. \& Roell, A. (1983), "Rural growth linkages: household expenditure patterns in Malaysia and Nigeria". Washington DC: IFPRI. (Research Report No. 41).

[7]. Irz, X., Lin, L., Thirtle, C., \& Wiggins, S. (2001). "Agricultural Productivity Growth and Poverty Alleviation, Development Policy Review”, 19 (4), 449-466.

[8]. Landesmann, Michael Alroy (2000): "Structural Change in the Transition Economies", 1989 to 1999, The Vienna Institute for International Economic Studies.

[9]. Park, S.H. (1989) Linkages between industry and services and their implications for urban employment generation in developing countries. Journal of Development Economics, 30(2), 359-79;

[10]. Strategy of actions in five priority directions of the Republic of Uzbekistan for 2017-2021 ("Priorities of economic development and liberalization");

[11]. Strout, A.M. (1958). "Primary employment effects of alternative spending: programs" The Review of Economics and Statistics 15(4) 319328 